\title{
Effect of varying planting density on weed infestation, crop phenology, yield, and fiber quality of cotton under different sowing methods
}

Binish Khan ${ }^{1}$, Muhammad Ishfaq ${ }^{2 *}$, Khadija Murtza ${ }^{1}$, Zarina Batool ${ }^{2}$, Nasir $\mathrm{Ali}^{2}$, Muhammad Shafique Aslam², Imran Khan ${ }^{2}$ and Shakeel Ahmed Anjum ${ }^{2}$

1. Department of Botany, University of Agriculture, Faisalabad, 38040-Pakistan

2. Department of Agronomy, University of Agriculture, Faisalabad, 38040-Pakistan

*Corresponding author's email: ishfaq2727@gmail.com

Citation

Binish Khan, Muhammad Ishfaq, Khadija Murtza, Zarina Batool, Nasir Ali, Muhammad Shafique Aslam, Imran Khan and Shakeel Ahmed Anjum. Effect of varying planting density on weed infestation, crop phenology, yield, and fiber quality of cotton under different sowing methods. Pure and Applied Biology. Vol. 10, Issue 3, pp676-691. http://dx.doi.org/10.19045/bspab.2021.100070

\begin{tabular}{llll}
\hline \hline Received: 01/08/2020 & Revised: 29/10/2020 & Accepted: 09/11/2020 & Online First: 26/11/2020 \\
\hline \hline
\end{tabular}

\section{Abstract}

The sowing method and planting density of cotton (Gossypium hirsutum L.) are two important tools for enhancing crop productivity and quality while reducing weeds infestation. This study was conducted to explore how to weed infestation, crop morphology, yield-related traits and fiber quality of cotton may be improved through the sowing method and planting density. Cotton line PB-896 was cultivated and hand thinned to maintain 59, 259 plants ha $^{-1}, 44,444$ plants ha $^{-1}$ and 35, 555 plants $\mathrm{ha}^{-1}$ under three sowing methods (flat sowing, ridge sowing, and bed sowing) at Postgraduate Agriculture Research Station (PARS), University of Agriculture, Faisalabad, Punjab during 2017 and 2018. The experiment was laid out in Randomized Complete Block Design (RCBD) with a split-plot arrangement. Obtained results revealed that ridge sowing of cotton reduced the weed density by $25 \%$ in comparison to flat sowing. However, bed sowing of cotton increased the sympodial branches, opened bolls plant ${ }^{-1}$, lint yield, seed index, and seed cotton yield by $48 \%, 52 \%, 38 \%, 39 \%$, and $50 \%$ respectively as compared to flat sowing. Higher planting density found to be more efficient in weed reduction, however, lower planting density improved the monopodial branches (18\%), total bolls plant ${ }^{-1}(14 \%)$, boll weight (16\%), seed index (17\%), and seed cotton yield (23\%) than higher planting density. In terms of fiber quality, sowing methods only influenced the fiber uniformity that was comparatively higher in bed planting, while planting density only increased the fiber fineness that was better in lower planting density. In conclusion, the bed sowing method along with lower planting density found to be more efficient in improving crop morphology, yield, and yield-related traits.

Keywords: Cotton; Planting density; Quality; Sowing method; Weed infestation; Yield 


\section{Introduction}

Cotton (Gossypium hirsutum L.) is not only cultivated primarily for fiber but it is also considered as cash crop across the world because it is an important commodity for oil, animal feed, and the fiber industry [13]. After India, China, and the USA, Pakistan is ranked $4^{\text {th }}$ in cotton production. Cotton crop is not only providing a major share in Pakistan's export earnings but also contributes to gross domestic product (1\%) and agricultural value addition (5.5\%). In the year 2018, cotton production increased by $11.8 \%$ as compared to the previous year due to the appropriate rainfall interval, better economic return, and subsidized rate of inputs [4]. However, climate change widely affecting the productivity of the agriculture system, especially cotton productivity in Pakistan [5, 6]. Changing rainfall patterns, more extreme weather conditions, and high temperature are increasing the vulnerability of cotton growth and production along with other crops [7-10]. Moreover, cotton productivity is stagnant in Pakistan due to poor management practices: inadequate plant population, traditional sowing method, weed infestation, flare-up insect pest pressure, and diseases [11]. Under the scenario where environmental circumstances are not in control of humans, the only available alternative to enhance crop productivity is to adjust the agronomic practices [12, 13]. Among various management practices to enhance cotton productivity, suitable sowing method and planting density are the most important practices toning to the available ecological condition and step toward cotton mechanization $[11,14]$.

In Pakistan, the traditional sowing method (flat sowing) resulted in a patchy plant population due to poor germination. Moreover, the occurrence of rainfall soon after the seeding may result in crust formation and failure of seedling emergence. Under unusual rainfall patterns, the options of raised bed sowing and ridge sowing have the potential to ensure the uniform seedling emergence and plant population that are key factors to harvest profitable yield [15]. As compared to flat sowing, ridge sowing of cotton amended the soil physical indices (soil moisture content=SMC and bulk density), root penetration, and proliferation due to less resistance and enhanced the seedling emergence [16]. Butter et al. [17] and Patel et al. [18] stated that ridge sowing has improved the lint yield in comparison to flat sowing. Previous research findings divulged that the ridge sowing technique has also increased the seed cotton yield [19, 20] while reducing the weed infestation and weed biomass production [21]. Maqbool et al. [22] defined that growth and weed density may vary under different sowing methods, as in flat sowing weeds seed are contemporary homogeneously on soil whereas in bed and ridge sowing technique weeds seeds may be confined to some part. Similarly, bed sowing technique is superior to conventional sowing because the bedfurrow planting system eliminated the crust formation, enhanced the germination and emergence of seedling [23, 24], provided uniform and optimum plant population [15], increased lint yield by $25 \%$ [25] and seed cotton yields [26-29]. Other allied benefits of improved sowing techniques are increased resources use efficiency (water, fertilizer, seed, and land) [30-33] and better weed management [22].

After the sowing method, the key factor that influences the cotton growth and yield is plant density [34]. The goal of maximum yield and better quality could be achieved by the optimum plant population that is decided based on the cultivar, cropping system, planting date, and environmental condition $[2,11,35,36]$. However, a wide range of plant population showed a stable yield due to the difference in total bolls plant $^{-1}$ and boll weight [37-39]. In several countries, narrow plant spacing resulted in increased crop productivity and reduced weed infestation and weed dry matter production [15, 40, 41]. Similarly, Iqbal et al. [42] and Zhi et al. [43] highlighted that 
cotton cultivation in narrow plant spacing resulted in higher yield due to the extra plant population per unit area. Moreover, narrow plant spacing could be an effective tool to manage cotton leaf curl virus and weeds infestation [13, 41, 44]. Contrarily, in wider plant spacing higher yield was because of increased bolls plant ${ }^{-1}$ and boll weight $[19,42,45]$. Therefore, the selection of suitable sowing methods according to the prevalent climatic conditions along with suitable planting density is even more vital for enhancing cotton productivity and quality. Yield changing aspects and quality of cotton under the influence of the sowing method and planting densities are studied separately or with other factors. However, information about weed occurrence, yield, and quality dynamics of cotton under the influence of the sowing method with different planting density is rare. Thus the prime objective of this experiment was to investigate how weed infestation, crop morphology, yield, and quality of cotton are predisposed by different sowing methods with varying planting density.

\section{Materials and methods \\ Experimental location}

This experiment was led at PARS, University of Agriculture, Faisalabad, Punjab during the Kharif (summer) seasons of 2017 and 2018. Before commencing the experiments, in each year the soil sampling was done from the experimental field. The soil samples from different locations of field up to a depth of $0.30 \mathrm{~m}$ were procured by following the zig-zag method of soil sampling. The soil samples were analyzed for physical, chemical, and biological properties as detailed in (Table 1). The soil of the experimental site belongs to the Lyallpur soil series as per the Food and Agriculture Organization (FAO) soil classification [46] and hyperthermic Ustalfic, Haplagrid, aridisol-fine-silty, mixed soil as per United States Department of Agriculture (USDA) classification. The climate of the experimental location (Faisalabad) is semiarid to subtropical, monsoonal with temperature variation in summer from maximum $\left(47.5\right.$ and $\left.38.8^{\circ} \mathrm{C}\right)$ to minimum temperatures (6 and $17^{\circ} \mathrm{C}$ ) 2017 and 2018, respectively. The total rainfall and other weather indices for the study period are represented in (Table 2).

\section{Plant material}

The de-linted seed of Cotton line PB-896 having a $60 \%$ germination rate procured from the Department of Plant Breeding and Genetics, University of Agriculture, Faisalabad, Punjab.

\section{Experimentation}

In both years experiments were laid out in randomized complete block design under split-plot arrangement randomizing sowing techniques (flat sowing, ridge sowing, and bed sowing) in main plots and planting densities $(0.225 \mathrm{~m}$ plat-plant distance $=59$, 259 plants, $0.30 \mathrm{~m}$ plat-plant distance $=$ 44,444 and 0.375 plat-plant distance $=35$, $555)$ is sub-plots with 3 replications having net plot size $10 \mathrm{~m} \times 6 \mathrm{~m}$. The crop was sown on May 27 and 25, 2017, and 2018, respectively. Pre-sowing saturation irrigation (10 cm depth) was applied each year. Rotavator was operated to manage the previous crop stubbles when soil mellowness was physically appropriate for cultivation. The field was prepared by three cultivation (using cultivator) followed by planking. Tractor-mounted ridger, as well as bed-shaper, were castoff to create ridges and bed ( $0.75 \mathrm{~m}$ wide), respectively.

In furrow-ridge and furrow-bed, ridge to ridge and bed to bed distance was $0.75 \mathrm{~m}$. Tractor mounted seed drill having adjustable seed rate was used for flat sowing of cotton in $0.75 \mathrm{~m}$ apart rows. At field capacity soil moisture, dry seeds are drilled at $20 \mathrm{~kg} \mathrm{ha}^{-1}, 24 \mathrm{~kg} \mathrm{ha}^{-1}$ and $34 \mathrm{~kg}$ $\mathrm{ha}^{-1}$ seed rate to maintain the respective planting densities. In ridge sowing, cotton seeds ( 5 per hill) were manually dibbled to maintain the specific planting densities, while in bed sowing, on both sides of the bed, 5 seeds per hill were dibbled to maintain the specific planting densities. The dibbled seeds were covered with soil. Irrigation was applied in ridge and bed sowing techniques and seeding was done on 
the moist edge of the ridge and bed, respectively. Manual thinning was done to maintain respective planting densities at the fourth leaf stage of the crop (BBCF identification code $=14$ ) [47]. Postemergence herbicides (Fazelofoop methyl $250 \mathrm{ml}$ in 100-liter water) were applied at 30 days after sowing= DAS to control the weeds using a shoulder-mounted knapsack spray machine with T-Jet nozzle. Nitrogen (N $200 \mathrm{~kg} \mathrm{ha}^{-1}$ ), phosphorous ( P $85 \mathrm{~kg} \mathrm{ha}^{-}$ ${ }^{1}$ ), potassium (K $95 \mathrm{~kg} \mathrm{ha}^{-1}$ ), boron ( B $5 \mathrm{~kg}$ $\mathrm{ha}^{-1}$ ), and zinc ( $\mathrm{Zn} 3 \mathrm{~kg} \mathrm{ha}^{-1}$ ) were applied to fulfill the fertilizers requirement using urea, di-ammonium phosphate (DAP), murate of potash (MOP), zinc sulphate $33 \%$, and boric acid $17 \%$ as the source, respectively. The entire dose of $\mathrm{P}, \mathrm{K}, \mathrm{B}$, and $\mathrm{Zn}$ along with one-third dose of $\mathrm{N}$ was applied before sowing. While remaining $\mathrm{N}$ was applied in two equal splits at floral bud initiation $(\mathrm{BBCF}$ identification code $=51$ ) and beginning of boll opening (BBCF identification code $=81$ ) stages [47]. Canal irrigation was used to irrigate the crop during the entire growth period. Six irrigations in total were applied to irrigate the crop in each season and the last irrigation was applied on 15 and 6, August of 2017, and 2018. Bollworm and other insects (aphid, jassid, whitefly, thrips, mites, and cotton mealybug) were kept under the economic threshold level by the application of insecticides (Polytrien $\mathrm{C}=$ $1250 \mathrm{ml} \mathrm{ha}^{-1}$, orange $=1875 \mathrm{ml} \mathrm{ha}^{-1}$, and hathora $=315 \mathrm{ml} \mathrm{ha}^{-1}$ ). In each year crop was harvested in two pickings. First picking was done on $5^{\text {th }}$ and $9^{\text {th }}$ October of 2017 and 2018, respectively, while second piking was done $1^{\text {st }}$ and $6^{\text {th }}$ November of 2017 and 2018, respectively.

\section{Observation and measurements}

In both years of experimentation, individual and total weed density was recorded from 3 randomly selected quadrates $(0.5 \mathrm{~m} \times 0.5$ $m$ ) in each experimental unit at 25 DAS. Weeds were identified in each quadrate and counted carefully and the average of three quadrates is represented for total weed density and individual weed density $\mathrm{m}^{-2}$.
Ten plants in each plot were tagged to note the plant height $(\mathrm{cm})$, monopodial branches plant $^{-1}$, sympodial branches plant ${ }^{-1}$, total bolls plant ${ }^{-1}$, opened bolls branches plant ${ }^{-1}$, and unopened bolls plant ${ }^{-1}$ and average values were taken.

Before commencing $2^{\text {nd }}$ picking, fifty matured opened bolls from tagged plants of each plot were taken. After sun-drying, boll weight was measured by using a digital electronic weighing balance. Harvested bolls were manually ginned to find out lint yield $(\mathrm{g})$, while the formula given by Singh et al. [48] was used to measure ginning out turn (GOT). Roller type laboratory ginning machine was used to obtain seed cotton from both pickings of each experimental unit. 100-seed cotton were counted from each treatment and weighed to find the 100seed cotton weight, while seed cotton yield ( $\mathrm{kg} \mathrm{ha}{ }^{-1}$ ) was measured by weighing obtained seed cotton from each experimental unit. To measure fiber length $(\mathrm{cm})$ and strength $\left(\mathrm{g} \mathrm{tex}^{-1}\right)$, the method of Moore [49] was followed, while spin lab high volume instrument HVI-900 was used to measure fiber uniformity (\%) as well as the fineness $(\mu \mathrm{g}$ inch-1) as explained by Ehsanullah [14].

\section{Data analysis}

Recorded data, on all parameters, were analyzed statistically by using Statistics 10 package (student edition) with Fisher's analysis of variance technique [50]. The RCBD with a split-plot arrangement was used for data analysis. Interaction between years, sowing techniques, and planting densities were non-significant for all parameters, except for weed density. Therefore, pooled data (of 2017 and 2018) for all parameters are presented except weed density. Tukey's honestly significant difference test at $5 \%$ probability level was used to compare treatment means.

\section{Results}

\section{Weed density}

Prevailing weed flora in the experimental field consisted of broad leaves weeds, sedges, and grassy weeds. During both years of experimentation, weeds species 
recorded in all experimental units were Trianthema portulacasterum L. (carpet weed) and Convolvulus arvensis L. (field bindweed) under the grassy weeds category. Cyperus rotundus L. (purple nutsedge) was only sedge weed observed in the experimental field, while Dactyloctenium aegyptium L. (Egyptian finger grass) and Cynodon dactylon $\mathrm{L}$. (barmuda grass) were the existing broad leaves weed (Table 3).

Total weed density of grassy weeds, broad leaves weeds, and sedge weed (Figure 1) as well as individual weed densities were substantially influenced by different sowing approaches and planting densities of cotton in both years of experimentation. However, the interactive effect of the sowing method and planting density did not affect the weed density (total and individual) significantly. Higher weed density (C. rotundus, $C$. dactylon, and $C$. arvensis) was recorded in 2018 as compared to the year 2017, while the plant population of $D$. aegyptium and $T$. portulacasterum was lower in 2018 . The lowest total weed density was recorded in ridge sowing while the highest total weed density in both years of experimentation was recorded in flat sowing (Figure $1 \mathrm{~A}$ ). Higher planting density (59259 plant ha ${ }^{-1}$ ) reduced the total weed density, while the highest weed infestation was recorded in lower planting density $\left(35,555\right.$ plants ha $\left.{ }^{-1}\right)$ of cotton (Figure $1 \mathrm{~B}$ ). Amongst individual weed density, $C$. rotundus, $C$. dactylon, and $T$. portulacasterum were the most dominant weed species in all experimental units. It was observed that the ridge sowing method reduced the individual weed density of $C$. rotundus, $C$. dactylon, $T$. portulacasterum, C. arvensis, and D aegyptium by $24 \%, 21 \%$, $31 \%, 28 \%$, and $33 \%$, respectively, then flat sowing (Table 3). While weed density in ridge and bed sowing techniques were statistically comparable. Regardless of weed species, individual weed density increased with reducing plant density of cotton, successively (Table 3 ).

\section{Plant phenology and morphology}

Data about plant phenology indicated that sowing methods did not influence any phenological trait significantly, while planting density only influenced the boll maturation period. Similarly, the sowing method influenced the plant morphological traits except for plant height, the number of monopodial branches, and unopened bolls plant $^{-1}$, while planting density influenced all morphological attributes of cotton significantly except opened bolls plant ${ }^{-1}$ (Table 4). It was observed that boll maturation period, plant height, monopodial branches, sympodial branches, total bolls plant ${ }^{-1}$ and opened bolls plant ${ }^{-1}$ were significantly increased with reducing planting density $(44,444$ and 35,555 plants $\left.\mathrm{ha}^{-1}\right)$, while minimum values for morphological traits were recorded in the highest planting density $\left(59,259\right.$ plants ha ${ }^{-}$ ${ }^{1}$ ). Regarding sowing methods, the bed sowing method gave the highest values for morphological traits (sympodial branches, the total number of bolls plant ${ }^{-1}$ and opened bolls plant ${ }^{-1}$ ) that were similar (statistically) to ridge sowing technique, however, these were higher $(48 \%, 47 \%$, and $52 \%)$ as compared to flat sowing (Table 4).

\section{Yield related attributes}

It was observed that all yield-related traits were substantially influenced by sowing methods and planting density except GOT. Interaction of the sowing method and planting density did not affect any yieldrelated traits (Table 5). Maximum yieldrelated traits (boll weight $(\mathrm{g})$, seed cotton yield plant $^{-1}(\mathrm{~g})$, lint yield $(\mathrm{g})$, seed index $(\mathrm{g})$, and seed cotton yield $\mathrm{ha}^{-1}(\mathrm{~kg})$ were noted in bed sowing method that were higher than flat sowing by 16, 49, 38, 29 and $50 \%$, respectively (Table 5).

Similarly, cultivation of cotton at 75 $\mathrm{cm} \times 37.5 \mathrm{~cm}$ plant spacing $(35,555$ plants $\mathrm{ha}^{-1}$ ) gave the highest single boll weight, seed cotton yield plant ${ }^{-1}$, lint yield, seed index, and seed cotton yield $\mathrm{ha}^{-1}$, while reducing the plant spacing reduced the yield-related traits significantly. As compared to higher planting density of 
cotton $\left(59,259\right.$ plants $\left.\mathrm{ha}^{-1}\right)$, cultivation of cotton with lower planting density $(35,555$ plants $\mathrm{ha}^{-1}$ ) improved the single boll weight, seed cotton yield plant $^{-1}$, lint yield, seed index, and seed cotton yield ha ${ }^{-1}$ by 16,25 , 27,17 , and $23 \%$, respectively (Table 5).

\section{Fiber quality}

Data indicated that sowing methods only influenced the fiber uniformity significantly while planting density only profound effect on fiber fineness. Interaction of sowing methods and planting density was also found to be non-significant for fiber quality (Table 5). It was observed that bed sowing of cotton improved the fiber uniformity by $7 \%$ and $4 \%$ as compared to flat sowing and ridge sowing, respectively. Likewise, fiber fineness was improved by lowering the plating density of cotton $\left(35,555\right.$ plants $\left.\mathrm{ha}^{-1}\right)$ as compared to higher planting density (Table 5).

\section{Discussion:}

This study showed that sowing methods significantly influenced individual as well as total weed density $\mathrm{m}^{-2}$, (Table $3 \&$ Fig. 1), some morphological traits (Table 4), almost all yield-related traits, and fiber uniformity (Table 5). Similarly, the variation of planting density also influenced the weed density, morphological attributes, yield-related traits, and fiber fineness (Table 3-5 \& Fig. 1).

\section{Weed infestation}

In cotton cultivation, weeds infestation reduced the cotton yield by $10-90 \%$ [35] depending on the type of weed flora, cultural practices (sowing method, plant spacing, and fertilizer application), and crop varieties. Reduction in cotton yield due to weed infestation can be explained as weed has an extraordinary ability to compete for space, food, and light $[29,51]$. In 2018, total and individual weed density (except carpet weed and Egyptian finger grass) were comparatively higher than in 2017 that might be associated with more rainfall events and suitable weather conditions soon after the emergence of the crop. Regarding the sowing method, the highest weed population was recorded in flat sowing in comparison to the ridge and bed sowing. This higher weed population in flat sowing could be explained as the weeds seeds are present homogenously at soil surface while in ridge and bed sowing seeds might be confined to the specific area due to alteration of micro-topography in ridge and bed formation [22]. Similarly, Nadeem et al. [21] discussed that the ridge sowing method abridged the density of $C$. rotundus, $T$. portulacastrum, $C$. dactylon and $C$. arvensis significantly as compared to flat sowing because due to changing land formation from flat to ridges and beds some of the weed seeds exposed. The exposed seeds might be unable to germinate due to weather extremities. Improved sowing techniques (bed and flat sowing) proven to be more efficient because these methods provide suitable soil conditions for crop establishment and root growth and development by reducing the root penetration resistance and improving soil physical properties [16]. Moreover, ridge and bed sowing methods are more efficient as compared to flat sowing in terms of resource use and weed control [52-54]. Increasing planting density reduced the weed infestation that could be explained as the higher population pressure and intercrop competitive ability of $\mathrm{Bt}$ cotton reduced the weed persistence. Moreover, the smothering potential of higher planting density reduced weed occurrence [48]. Contrarily, the reduction of plating density promotes weed emergence and density due to less intercrop competition [55].

\section{Sowing methods}

Amongst three sowing methods, bed and ridge sowing methods proved to be more efficient in terms of resource use, crop establishment, growth, yield, and quality of cotton. Planting methods play an important role not only in establishing cotton stands but also assists the conversion of solar radiation into chemical energy in crop plants but also help in balancing the plant to plant interaction for solar radiation to get maximum yield [56]. Moreover, an effective sowing method also helps to 
increase the productivity of the crop through improving growth and development [57]. Improved sowing technique (bed or ridge) are efficient methods because of having the potential to increase the soil's physical properties (soil moisture contents), improve root penetration, and the emergence of seedlings $[16,26,53,55]$. It was observed that improved sowing techniques reduced the boll maturation period as compared to flat sowing but this reduction was nonsignificant (Table 4).

Similarly, Wang et al. [52] explained that due to better utilization of resources and aeration, bed plating reduced the flowering and boll maturation period. Amongst crop morphological attributes, bed sowing gave the highest values for sympodial and monopodial branches plant ${ }^{-1}[28,58]$ as well as opened bolls plant-1 [33, 59] followed by ridge sowing and minimum, were recorded in flat sowing that could be explained as improved root growth and penetration to acquire water and nutrients, better aeration and minimizing the chances of direct water contact to crop stem [26]. Moreover, the bed or ridge sowing method is a suitable method to ensure the optimum plant population while increasing yieldrelated traits and yield during an unequal period of rain [5. 27, 61]. Previous research studies indicated that the bed sowing technique increased the boll weight, seed index, lint yield, and seed cotton yield as compared to flat sowing $[11,16,25,33$, 60]. Similarly, Soomro et al. [45] concluded that in cotton-wheat rotation, bed sowing of cotton increased the yield by $35 \%$ than flat sowing. However, different sowing methods did not influence the number of monopodial branches, unopened bolls plant $^{-1}$, and GOT that is also highlighted by Akbar et al. [33] and Ali et al. [15].

In the case of fiber quality, except fiber uniformity, all other quality traits were alike in diverse sowing techniques (Table 5) which were also concluded in previous research studies $[14,36]$.

\section{Planting density}

Planting density influenced the boll maturation period, most of the morphological, and yield-related attributes, and fiber fineness substantially (Tables 4 \& 5). It was observed that reducing plating density reduced the boll maturation period that might be due to proper utilization of sunlight, aeration, and uptake of nutrients and water and less competition for resources among plants [62]. Amongst morphological attributes, unopened bolls plant $^{-1}$ were remained statistically similar, while all other traits (sympodial branches, monopodial branches, bolls plant ${ }^{-1}$, and opened bolls plant ${ }^{-1}$ ) were higher in lower planting density treatment. Reduced morphological attributes in higher density can be explained as the excessive vegetative growth under dense population resulted in shading, etiolation, boll rot, abscission of fruit, and delayed maturity [4, $14,36,38]$.

Contrarily, increasing plant to plant spacing resulted in reduced planting density, increased branches plant ${ }^{-1}$ (sympodial as well as monopodial), and bolls plant ${ }^{-1}$ (Table 4) that was due to higher fruit retention on both types of branches $[14,37$, 38]. Similarly, lower planting density also improved the yield and yield-related traits as compared to a higher density plant population that could be related to improved morphological attributes (higher no. of bolls plant ${ }^{-1}$ and branches plant ${ }^{-1}$ ) and better utilization of resources and low competition among plants $[36,40,62]$. While, higher planting density completion among plants for resources (light, water, nutrient, and space) was higher that cause a reduction in final yield $[63,64]$. Moreover, a balanced and optimum planting density improved the microenvironment by increasing light interception and soil water evaporation that resulted in higher yield and improved water use efficiency [65-67]. Kerby et al. [68] and Heitholt et al. [69] discussed that alone planting density influenced the photosynthesis capacity, plant height, fruit production, and boll size, 
location of bolls, numbers of bolls, maturity, and yield.

In terms of fiber quality, planting density did not influence the fiber quality except fiber fineness (Table 5). It was observed that lower planting density improved the fiber fineness as compared to the higher density that could be attributed to properly assimilated translocation and improved source-sink relation. Previous research findings of Hussain and Qasim [70] and Ehsanullah et al. [14] also explained that fiber quality remained unaffected under different planting density.
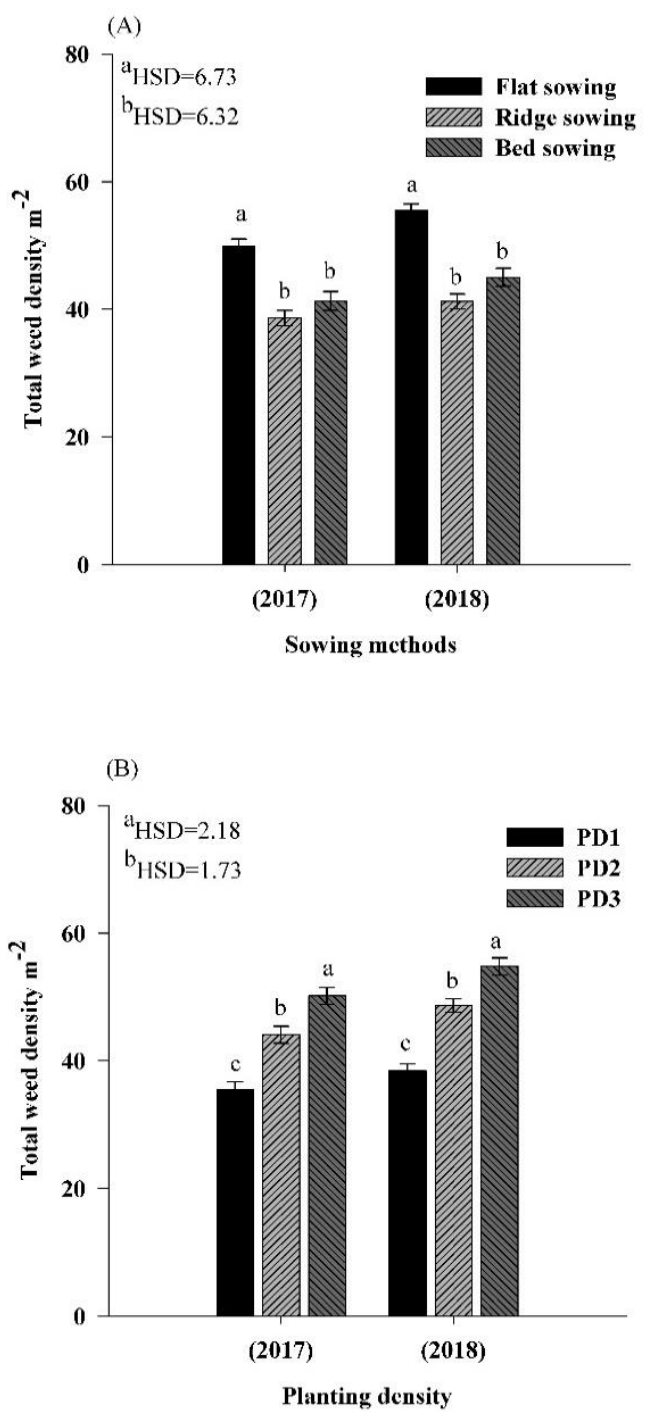

Figure 1. Total weed density under different sowing techniques and planting density of cotton during 2017 and $2018 ; P D=$ planting density; $P D 1=75 \mathrm{~cm} \times 22.5 \mathrm{~cm}(59259$ plants ha $\left.^{-1}\right)$; PD2= $75 \mathrm{~cm} \times 30 \mathrm{~cm}\left(44444\right.$ plants ha $\left.{ }^{-1}\right)$; PD3=75 cm $\times 37.5 \mathrm{~cm}\left(35555\right.$ plants ha $\left.{ }^{-1}\right)$; $\mathrm{HSD}=$ honestly significant difference; ${ }^{\mathrm{a}} \mathrm{HSD}=2017$; ${ }^{\mathrm{b}} \mathrm{HSD}=2018$; Bars are treatment means \pm standard errors; Values sharing different lettering for a parameter above the bar are significantly different $(p \leq 0.05)$ by the Tukey's HSD test within same year 
Table 1. Physical, chemical, and biological properties of experimental soil

\begin{tabular}{|c|c|c|c|c|c|c|c|c|c|}
\hline \multirow{2}{*}{$\begin{array}{l}\text { Soil depth } \\
(\mathrm{cm})\end{array}$} & \multirow{2}{*}{$\begin{array}{l}\text { Bulk density } \\
\left(\mathrm{mg} \mathrm{m}^{-3}\right)\end{array}$} & \multirow{2}{*}{$\begin{array}{l}\text { Organic matter } \\
(\%)\end{array}$} & \multirow{2}{*}{$\begin{array}{l}\text { Total N } \\
(\%)\end{array}$} & \multirow{2}{*}{$\begin{array}{l}\text { Available P } \\
\left(\mathrm{mg} \mathrm{kg}^{-1}\right)\end{array}$} & \multirow{2}{*}{$\begin{array}{l}\text { Exchangeable K } \\
\left(\mathrm{mg} \mathrm{kg}^{-1}\right)\end{array}$} & \multirow{2}{*}{ Zinc $\left(\mathrm{mg} \mathrm{kg}^{-1}\right)$} & \multicolumn{3}{|c|}{ Particle size distribution (\%) } \\
\hline & & & & & & & Sand & Silt & Clay \\
\hline $0-15$ & 1.49 & 0.98 & 0.05 & 08.9 & 180 & 1.67 & 45.0 & 28.0 & 27.0 \\
\hline $15-30$ & 1.55 & 0.72 & 0.04 & 07.6 & 136 & 0.87 & 43.5 & 29.0 & 27.5 \\
\hline Remarks & Low & Low & Low & Low & Medium & Deficient & \multicolumn{3}{|c|}{ Sandy loam } \\
\hline
\end{tabular}

$\mathrm{N}=$ Nitrogen; $\mathrm{P}=$ Phosphorus; $\mathrm{K}=$ Potassium; each value is an average of two years

Table 2. Weather data during the cotton season of 2017 and 2018 at the experimental site

\begin{tabular}{|c|c|c|c|c|c|c|c|c|c|c|c|c|}
\hline \multirow{3}{*}{ Month } & \multirow{2}{*}{\multicolumn{2}{|c|}{ Rainfall $^{\mathrm{a}}(\mathrm{mm})$}} & \multicolumn{6}{|c|}{ Temperature ${ }^{\circ} \mathbf{C}$} & \multirow{2}{*}{\multicolumn{2}{|c|}{$\begin{array}{c}\text { Relative humidity }^{\mathrm{c}} \\
(\%)\end{array}$}} & \multirow{2}{*}{\multicolumn{2}{|c|}{$\begin{array}{l}\text { Monthly average } \\
\text { sunshine }^{c}(h)\end{array}$}} \\
\hline & & & \multicolumn{2}{|c|}{ Monthly maximum ${ }^{b}$} & \multicolumn{2}{|c|}{ Monthly minimumb } & \multicolumn{2}{|c|}{ Monthly mean ${ }^{c}$} & & & & \\
\hline & 2017 & 2018 & 2017 & 2018 & 2017 & 2018 & 2017 & 2018 & 2017 & 2018 & 2017 & 2018 \\
\hline May & 10.1 & 21.6 & 41.1 & 40.3 & 26.0 & 23.7 & 33.5 & 32.0 & 29.8 & 29.8 & 09.2 & 08.6 \\
\hline June & 41.6 & 92.0 & 39.8 & 39.8 & 27.3 & 27.9 & 33.5 & 33.9 & 44.5 & 56.5 & 08.5 & 9.38 \\
\hline July & 117 & 195 & 38.5 & 38.0 & 28.9 & 28.0 & 33.7 & 33.0 & 70.0 & 70.2 & 07.0 & 07.9 \\
\hline August & 66.0 & 05.4 & 38.1 & 39.0 & 28.6 & 29.5 & 33.4 & 34.2 & 68.9 & 67.4 & 7.87 & 08.5 \\
\hline September & 35.6 & 41.7 & 36.7 & 37.2 & 24.4 & 25.6 & 30.6 & 31.4 & 67.7 & 65.1 & 08.8 & 08.7 \\
\hline October & 0.00 & 0.00 & 35.0 & 32.6 & 19.2 & 18.7 & 27.1 & 25.6 & 68.2 & 64.4 & 07.5 & 8.81 \\
\hline November & 01.5 & 00.6 & 24.1 & 27.1 & 11.8 & 12.7 & 18.0 & 19.9 & 84.6 & 74.6 & 3.65 & 6.68 \\
\hline
\end{tabular}

${ }^{\mathrm{a}}$ Total monthly rainfall, ${ }^{\mathrm{b}}$ Monthly maximum and minimum temperature are highest and lowest temperatures observed during the whole month, ${ }^{\mathrm{c}}$ Monthly mean, relative humidity, and sunshine are the monthly averages

Table 3. Influence of different sowing techniques and planting density of cotton on weeds density in 2017 and 2018

\begin{tabular}{|c|c|c|c|c|c|c|c|c|c|c|}
\hline \multirow{3}{*}{ Treatment } & \multicolumn{4}{|c|}{$\begin{array}{c}\text { Grassy weed } \\
\end{array}$} & \multicolumn{4}{|c|}{$\begin{array}{c}\text { Broad leaves weed } \\
\end{array}$} & \multirow{2}{*}{\multicolumn{2}{|c|}{$\begin{array}{c}\text { Sedge weed } \\
C \text {. rotundus } \mathrm{L} .\end{array}$}} \\
\hline & \multicolumn{2}{|c|}{ C. dactylon $\mathrm{L}$. } & \multicolumn{2}{|c|}{ D. aegyptium $\mathbf{L}$} & \multicolumn{2}{|c|}{ C. arvensis $\mathrm{L}$. } & \multicolumn{2}{|c|}{ T. portulacasterum $\mathrm{L}$. } & & \\
\hline & 2017 & 2018 & 2017 & 2018 & 2017 & 2018 & 2017 & 2018 & 2017 & 2018 \\
\hline \multicolumn{11}{|c|}{ Sowing Techniques (ST) } \\
\hline Flat sowing & $17.8^{\mathrm{a}}$ & $20.3^{\mathrm{a}}$ & $3.89^{\mathrm{a}}$ & $3.72^{\mathrm{b}}$ & $4.83^{\mathrm{a}}$ & $7.67^{\mathrm{a}}$ & $6.11^{\mathrm{a}}$ & $3.72^{\mathrm{a}}$ & $17.2^{\mathrm{b}}$ & $21.1^{\mathrm{a}}$ \\
\hline Ridge sowing & $14.3^{\mathrm{b}}$ & $15.7^{\mathrm{b}}$ & $2.89^{\mathrm{b}}$ & $2.18^{\mathrm{b}}$ & $3.72^{\mathrm{b}}$ & $5.33^{\mathrm{b}}$ & $4.67^{\mathrm{b}}$ & $2.11^{\mathrm{b}}$ & $13.0^{\mathrm{ab}}$ & $16.3^{\mathrm{b}}$ \\
\hline Bed sowing & $15.4^{\mathrm{ab}}$ & $17.3^{\mathrm{ab}}$ & $3.06^{\mathrm{a}}$ & $1.94^{\mathrm{b}}$ & $4.00^{\mathrm{b}}$ & $6.67^{\mathrm{ab}}$ & $5.22^{\mathrm{ab}}$ & $2.25^{\mathrm{b}}$ & $13.6^{\mathrm{b}}$ & $16.9^{b}$ \\
\hline$H S D(p \leq 0.05)$ & 2.93 & 3.20 & 0.68 & 0.55 & 0.65 & 1.48 & 1.31 & 0.31 & 3.86 & 3.38 \\
\hline \multicolumn{11}{|c|}{ Planting density $(P D)$} \\
\hline $\begin{array}{c}75 \mathrm{~cm} \times 22.5 \mathrm{~cm} \\
\left(59259 \text { plants } \mathrm{ha}^{-1}\right)\end{array}$ & $14.1^{\mathrm{b}}$ & $15.4^{\mathrm{c}}$ & $2.44^{\mathrm{c}}$ & $1.44^{\mathrm{b}}$ & $3.27^{\mathrm{c}}$ & $4.67^{c}$ & $4.22^{\mathrm{b}}$ & $2.11^{\mathrm{c}}$ & $11.4^{\mathrm{c}}$ & $14.8^{\mathrm{c}}$ \\
\hline
\end{tabular}




\begin{tabular}{|c|c|c|c|c|c|c|c|c|c|c|c|}
\hline \multicolumn{2}{|l|}{$\begin{array}{c}75 \mathrm{~cm} \times 30 \mathrm{~cm} \\
\left(44444 \text { plants } \mathrm{ha}^{-1}\right)\end{array}$} & $16.2^{\mathrm{a}}$ & $18.2^{\mathrm{b}}$ & $3.28^{b}$ & $2.39^{\mathrm{a}}$ & $4.22^{\mathrm{b}}$ & $7.11^{\mathrm{b}}$ & $5.56^{\mathrm{a}}$ & $2.72^{\mathrm{b}}$ & $14.8^{\mathrm{b}}$ & $18.2^{\mathrm{b}}$ \\
\hline \multicolumn{2}{|l|}{$\begin{array}{c}75 \mathrm{~cm} \times 37.5 \mathrm{~cm} \\
\left(35555 \text { plants } \mathrm{ha}^{-1}\right)\end{array}$} & $17.2^{\mathrm{a}}$ & $19.7^{\mathrm{a}}$ & $4.11^{\mathrm{a}}$ & $2.61^{\mathrm{a}}$ & $5.06^{\mathrm{a}}$ & $7.89^{\mathrm{a}}$ & $6.22^{\mathrm{a}}$ & $3.25^{\mathrm{c}}$ & $17.6^{\mathrm{a}}$ & $21.3^{\mathrm{c}}$ \\
\hline \multicolumn{2}{|l|}{$H S D(p \leq 0.05)$} & 1.15 & 1.38 & 0.52 & 0.36 & 0.57 & 0.70 & 0.69 & 0.47 & 1.77 & 1.66 \\
\hline \multicolumn{12}{|l|}{ Analysis of variance } \\
\hline Source & $D F$ & & & & & & & & & & \\
\hline$S T$ & 2 & $*$ & $*$ & $* *$ & $* *$ & $* *$ & $* *$ & $*$ & $*$ & $*$ & $*$ \\
\hline$P D$ & 2 & $*$ & $* *$ & $* *$ & $* *$ & $* *$ & $* *$ & $* *$ & $* *$ & $* *$ & $* *$ \\
\hline$S T \times P D$ & 4 & $N S$ & $N S$ & $N S$ & $N S$ & $N S$ & $N S$ & $N S$ & $N S$ & $N S$ & $N S$ \\
\hline
\end{tabular}

$\mathrm{DF}=$ Degree of freedom; NS $=$ not significant at $\mathrm{P}>0.05$; * = Significant at $\mathrm{P}<0.05$; **= Significant at $\mathrm{P}<0.01$; HSD $=\mathrm{Honestly}$ significant difference; Values sharing the same lettering for a parameter are statistically similar $(\mathrm{p} \leq 0.05)$ by the Tukey's HSD test

\begin{tabular}{|c|c|c|c|c|c|c|c|c|c|c|}
\hline \multicolumn{2}{|c|}{ Treatment } & $\begin{array}{c}\text { Floral bud } \\
\text { initiation }\end{array}$ & $\begin{array}{c}\text { Days to } \\
\text { flowering }\end{array}$ & $\begin{array}{c}\text { Boll maturation } \\
\text { period }\end{array}$ & $\begin{array}{c}\text { Plant } \\
\text { height }(\mathrm{cm})\end{array}$ & $\begin{array}{c}\text { Monopodial } \\
\text { branches }\end{array}$ & $\begin{array}{c}\text { Sympodial } \\
\text { branches }\end{array}$ & $\begin{array}{l}\text { Bolls } \\
\text { plant }^{-1}\end{array}$ & $\begin{array}{c}\text { Opened bolls } \\
\text { plant }^{-1}\end{array}$ & $\begin{array}{c}\text { Unopened bolls } \\
\text { plant }^{-1}\end{array}$ \\
\hline \multicolumn{11}{|c|}{ Sowing Techniques (ST) } \\
\hline \multicolumn{2}{|c|}{ Flat sowing } & $34.2^{\mathrm{a}}$ & $63.8^{\mathrm{a}}$ & $59.8^{\mathrm{a}}$ & $91.7^{\mathrm{a}}$ & $1.49^{\mathrm{a}}$ & $18.8^{\mathrm{b}}$ & $22.3^{\mathrm{b}}$ & $18.2^{\mathrm{b}}$ & $4.03^{\mathrm{a}}$ \\
\hline \multicolumn{2}{|c|}{ Ridge sowing } & $34.1^{\mathrm{a}}$ & $63.0^{\mathrm{a}}$ & $58.0^{\mathrm{a}}$ & $96.1^{\mathrm{a}}$ & $1.69^{\mathrm{a}}$ & $23.0^{\mathrm{ab}}$ & $31.3^{\mathrm{a}}$ & $25.9^{\mathrm{a}}$ & $5.39^{\mathrm{a}}$ \\
\hline \multicolumn{2}{|c|}{ Bed sowing } & $34.3^{\mathrm{a}}$ & $63.3^{\mathrm{a}}$ & $55.9^{\mathrm{a}}$ & $98.6^{\mathrm{a}}$ & $1.82^{\mathrm{a}}$ & $27.5^{\mathrm{a}}$ & $32.8^{\mathrm{a}}$ & $27.8^{\mathrm{a}}$ & $5.06^{\mathrm{a}}$ \\
\hline \multicolumn{2}{|c|}{$H S D(p \leq 0.05)$} & 7.43 & 12.8 & 6.75 & 9.68 & 0.70 & 5.25 & 1.67 & 3.88 & 4.64 \\
\hline \multicolumn{11}{|c|}{ Planting density $(P D)$} \\
\hline \multicolumn{2}{|c|}{$\begin{array}{c}75 \mathrm{~cm} \times 22.5 \mathrm{~cm} \\
\left(59259 \text { plants ha }^{-1}\right)\end{array}$} & $33.9^{\mathrm{a}}$ & $66.1^{\mathrm{a}}$ & $60.6^{\mathrm{a}}$ & $87.8^{\mathrm{b}}$ & $1.53^{\mathrm{b}}$ & $20.1^{\mathrm{b}}$ & $26.8^{\mathrm{b}}$ & $21.6^{\mathrm{b}}$ & $5.20^{\mathrm{a}}$ \\
\hline \multicolumn{2}{|c|}{$\begin{array}{c}75 \mathrm{~cm} \times 30 \mathrm{~cm} \\
\left(44444 \text { plants ha }{ }^{-1}\right)\end{array}$} & $34.6^{\mathrm{a}}$ & $62.4^{\mathrm{a}}$ & $58.2^{\mathrm{a}}$ & $96.4^{\mathrm{a}}$ & $1.67^{\mathrm{ab}}$ & $23.3^{\mathrm{ab}}$ & $29.0^{\mathrm{ab}}$ & $24.2^{\mathrm{ab}}$ & $4.89^{\mathrm{a}}$ \\
\hline \multicolumn{2}{|c|}{$\begin{array}{c}75 \mathrm{~cm} \times 37.5 \mathrm{~cm} \\
\left(35555 \text { plants ha }{ }^{-1}\right)\end{array}$} & $34.2^{\mathrm{a}}$ & $61.6^{\mathrm{a}}$ & $54.9^{\mathrm{b}}$ & $102.2^{\mathrm{a}}$ & $1.80^{\mathrm{a}}$ & $26.1^{\mathrm{a}}$ & $30.6^{\mathrm{a}}$ & $26.2^{\mathrm{a}}$ & $4.39^{\mathrm{a}}$ \\
\hline \multicolumn{2}{|c|}{$H S D(p \leq 0.05)$} & 2.21 & 6.02 & 2.96 & 8.63 & 0.14 & 4.37 & 3.00 & 3.73 & 3.99 \\
\hline \multicolumn{2}{|c|}{$\begin{array}{c}\text { Analysis of } \\
\text { variance }\end{array}$} & & & & & & & & & \\
\hline Source & $D F$ & & & & & & & & & \\
\hline$S T$ & 2 & $N S$ & $N S$ & $N S$ & $N S$ & $N S$ & $*$ & $* *$ & $* *$ & $N S$ \\
\hline$P D$ & 2 & $N S$ & $N S$ & $* *$ & $* *$ & $* *$ & $*$ & $*$ & $*$ & $N S$ \\
\hline$S T \times P D$ & 4 & $N S$ & $N S$ & $N S$ & $N S$ & $N S$ & $N S$ & $N S$ & $N S$ & $N S$ \\
\hline
\end{tabular}

$\mathrm{DF}=$ Degree of freedom; NS = not significant at $\mathrm{P}>0.05 ; *=$ Significant at $\mathrm{P}<0.05 ; * *=$ Significant at $\mathrm{P}<0.01$; HSD $=$ Honestly significant difference; Values sharing the same lettering for a parameter are statistically similar $(\mathrm{p} \leq 0.05)$ by the Tukey's HSD test 
Table 5. Influence of different sowing techniques and planting density on yield-related, yield and quality traits of cotton

\begin{tabular}{|c|c|c|c|c|c|c|c|c|c|c|c|}
\hline \multicolumn{2}{|c|}{ Treatment } & $\begin{array}{c}\text { Boll } \\
\text { weight }(\mathrm{g})\end{array}$ & $\begin{array}{c}\text { Yield } \\
\text { plant }^{-1}(\mathrm{~g})\end{array}$ & $\begin{array}{c}\text { Lint } \\
\text { yield }(\mathrm{g})\end{array}$ & $\begin{array}{c}\text { Seed } \\
\text { index }(g)\end{array}$ & $\begin{array}{c}\text { Ginning out } \\
\text { turn }(\%)\end{array}$ & $\begin{array}{c}\text { Cotton yield } \\
\text { ha }^{-1}(\mathrm{~kg})\end{array}$ & $\begin{array}{c}\text { Fiber } \\
\text { length }(\mathrm{cm})\end{array}$ & $\begin{array}{l}\text { Fiber strength } \\
\quad\left(\mathrm{g} \mathrm{tex}^{-1}\right)\end{array}$ & $\begin{array}{c}\text { Fiber } \\
\text { uniformity }(\%)\end{array}$ & $\begin{array}{c}\text { Fiber fineness } \\
\left(\mu \mathrm{g}_{\text {inch }}^{-1}\right)\end{array}$ \\
\hline \multicolumn{12}{|c|}{ Sowing Techniques (ST) } \\
\hline \multicolumn{2}{|c|}{ Flat sowing } & $2.94^{\mathrm{b}}$ & $51.1^{\mathrm{b}}$ & $23.1^{\mathrm{b}}$ & $3.76^{\mathrm{b}}$ & $46.4^{\mathrm{a}}$ & $1913^{\mathrm{b}}$ & $24.9^{\mathrm{a}}$ & $24.3^{\mathrm{a}}$ & $46.3^{\mathrm{b}}$ & $3.67^{\mathrm{a}}$ \\
\hline \multicolumn{2}{|c|}{ Ridge sowing } & $3.21^{\mathrm{ab}}$ & $61.5^{\mathrm{b}}$ & $26.0^{\mathrm{b}}$ & $4.37^{\mathrm{ab}}$ & $42.6^{\mathrm{a}}$ & $2310^{\mathrm{b}}$ & $25.4^{\mathrm{a}}$ & $24.6^{\mathrm{a}}$ & $47.6^{\mathrm{b}}$ & $4.13^{\mathrm{a}}$ \\
\hline \multicolumn{2}{|c|}{ Bed sowing } & $3.42^{\mathrm{a}}$ & $76.5^{\mathrm{a}}$ & $31.9^{\mathrm{a}}$ & $4.85^{\mathrm{a}}$ & $41.8^{\mathrm{a}}$ & $2870^{\mathrm{a}}$ & $26.2^{\mathrm{a}}$ & $25.0^{\mathrm{a}}$ & $49.7^{\mathrm{a}}$ & $4.61^{\mathrm{a}}$ \\
\hline \multicolumn{2}{|c|}{$H S D(p \leq 0.05)$} & 0.44 & 14.4 & 5.86 & 0.68 & 16.1 & 539.5 & 3.98 & 2.37 & 1.64 & 1.08 \\
\hline \multicolumn{12}{|c|}{ Planting density $(P D)$} \\
\hline \multicolumn{2}{|c|}{$\begin{array}{c}75 \mathrm{~cm} \times 22.5 \mathrm{~cm} \\
(59259 \text { plants } \\
\left.\mathrm{ha}^{-1}\right)\end{array}$} & $2.90^{\mathrm{b}}$ & $56.0^{\mathrm{b}}$ & $24.2^{\mathrm{b}}$ & $3.95^{\mathrm{b}}$ & $44.2^{\mathrm{a}}$ & $2103^{b}$ & $24.1^{\mathrm{a}}$ & $24.1^{\mathrm{a}}$ & $46.6^{\mathrm{a}}$ & $3.64^{\mathrm{b}}$ \\
\hline \multicolumn{2}{|c|}{$\begin{array}{c}75 \mathrm{~cm} \times 30 \mathrm{~cm} \\
(44444 \text { plants } \\
\left.\mathrm{ha}^{-1}\right)\end{array}$} & $3.31^{\mathrm{a}}$ & $64.1^{\mathrm{ab}}$ & $26.1^{\mathrm{ab}}$ & $4.42^{\mathrm{ab}}$ & $41.9^{\mathrm{a}}$ & $2398^{\mathrm{ab}}$ & $25.8^{\mathrm{a}}$ & $24.2^{\mathrm{a}}$ & $48.1^{\mathrm{a}}$ & $4.19^{\mathrm{ab}}$ \\
\hline \multicolumn{2}{|c|}{$\begin{array}{c}75 \mathrm{~cm} \times 37.5 \mathrm{~cm} \\
(35555 \text { plants } \\
\left.\mathrm{ha}^{-1}\right) \\
\end{array}$} & $3.36^{\mathrm{a}}$ & $68.9^{\mathrm{a}}$ & $30.7^{\mathrm{a}}$ & $4.61^{\mathrm{a}}$ & $44.9^{\mathrm{a}}$ & $2591^{\mathrm{a}}$ & $26.7^{\mathrm{a}}$ & $25.6^{\mathrm{a}}$ & $48.9^{\mathrm{a}}$ & $4.58^{\mathrm{a}}$ \\
\hline \multicolumn{2}{|c|}{$H S D(p \leq 0.05)$} & 0.41 & 9.65 & 4.91 & 0.60 & 7.47 & 359.5 & 2.97 & 3.83 & 5.65 & 0.72 \\
\hline \multicolumn{12}{|c|}{$\begin{array}{c}\text { Analysis of } \\
\text { variance }\end{array}$} \\
\hline Source & $D F$ & & & & & & & & & & \\
\hline$S T$ & 2 & $*$ & $* *$ & $*$ & $*$ & $N S$ & $* *$ & $N S$ & $N S$ & $* *$ & $N S$ \\
\hline$P D$ & 2 & $*$ & $*$ & $*$ & $*$ & $N S$ & $*$ & $N S$ & $N S$ & $N S$ & $*$ \\
\hline$S T \times P D$ & 4 & $N S$ & $N S$ & $N S$ & $N S$ & $N S$ & $N S$ & $N S$ & $N S$ & $N S$ & $N S$ \\
\hline
\end{tabular}

$\mathrm{DF}=$ Degree of freedom; NS= not significant at $\mathrm{P}>0.05$; *= Significant at $\mathrm{P}<0.05$; **= Significant at $\mathrm{P}<0.01$; HSD $=\mathrm{Honestly}$ significant difference; Values sharing the same lettering for a parameter are statistically similar $(\mathrm{p} \leq 0.05)$ by the Tukey's HSD test 


\section{Conclusion}

Sowing method and planting density are two key factors that are used to manage the weed infestation, improve the morphological, and yield-related attributes of cotton. The results of this experiment revealed that bed sowing of cotton proved to be more efficient for weed management while enhancing the yield and yield-related traits as compared to flat sowing. Similarly, the performance of the ridge sowing method in terms of weed management, enhancing yield, and morphological traits were comparable to bed sowing. In the case of planting density, where higher planting density ensures better weed management and more plant population per unit area at the same time morphological, yield, and yield-related traits were lower in higher planting density. Contrarily, optimum planting density as in $75 \times 30 \mathrm{~cm}$ or in $75 \times$ $37.5 \mathrm{~cm}$ plant spacing not only improved the crop morphology but also improved the yield, yield-related traits, and quality of cotton. Moreover, GOT and most of the other quality traits of cotton remained statistically similar in different sowing methods and planting geometries. In crux, it can be concluded that the bed sowing method having a planting density of 4-5 plants $\mathrm{m}^{-2}$ is feasible for maintaining higher productivity of cotton and it could be used for cotton mechanization in the cottonwheat cropping zone.

\section{Authors' contributions}

Conceived and designed the experiments: SA Anjum \& I Khan, Performed the experiments: B Khan, MS Aslam \& K Murtza, Analyzed the data: Z Batool \& K Murtza, Contributed materials/ analysis/ tools: M Ishfaq, N Ali \& B Khan, Wrote the paper: M Ishfaq \& Z Batool.

\section{Acknowledgment}

We especially obliged the Directorate of farms, Agronomic Research Farm, and Department of Agronomy, for administrative, manpower, and technical assistance during the study.

\section{References}

1. Dutt Y, Wang XD, Zhu YG, \& Li YY (2004). Breeding for high yield and fiber quality in colored cotton. Plant Breed 123: 145-151.

2. Dong $\mathrm{H}$, Kong $\mathrm{X}, \mathrm{Li} \mathrm{W}$, Tang $\mathrm{W}, \&$ Zhang D (2010). Effects of plant density and nitrogen and potassium fertilization on cotton yield and uptake of major nutrients in two fields with varying fertility. Field Crops Res 119: 106-113.

3. Dhokne A, Zingare M, Mahure A, \& Lutade S (2017). Design and fabrication of cotton boll picker machine. Int J Eng Res 4: 1907-1908.

4. Government of Pakistan (2018). Economic Survey of Pakistan 2017-18. Ministry of Food, Agriculture and Livestock, Economic Wing, Islamabad, Pakistan. pp. 20-21.

5. Government of Pakistan. (2015). Economic Survey of Pakistan 2014-15. Ministry of Food, Agriculture and Livestock, Economic Wing, Islamabad, Pakistan. pp. 20-21.

6. Amin A, Nasim W, Fahad S, Ali S, Ahmad S, Rasool A, Saleem N, Hammad HM, Sultana S R, Mubeen M, Bakhat HF, Ahmad N, Shah GM, Adnan M, Noor M, Basir A, Saud S, Rahman MH, \& Paz JO (2018). Evaluation and analysis of temperature for historical (1996-2015) and projected (2030-2060) climates in Pakistan using Sim CLIM climate model: Ensemble application. Atmos Res 213: 422-436.

7. Rosenzweig C, Jones JW, Hatfield JL, Ruane AC, Boote KJ, Thorburn P, Antle JM, Nelson GC, Porter C, Janssen S, Asseng S, Basso B, Ewert F, Wallach D, Baigorria G, \& Winter JM (2013). The agricultural model inter comparison and improvement project (AgMIP): protocols and pilot studies. Agric Meteorol 170: 166-182.

8. IPCC (2014). Climate Change 2014 Synthesis Report Summary Chapter for Policymakers 31 IPCChttp://dx.doi.org/10.1017/CBO978 1107415324.

9. Iqbal MA, Ping Q, Abid M, Muhammad MKS, \& Rizwan M (2016). Assessing 
risk perceptions and attitude among cotton farmers: A case of Punjab province. Pak Inter J Disaster Risk Reduc 16: 68-74.

10. Nasim W, Belhouchette H, Ahmad A, Habib-ur-Rahman M, Jabran K, Ullah K, Fahad S, Shakeel M, \& Hoogenboom G (2016). Modelling climate change impacts and adaptation strategies for sunflower in Pakistan. Outlook Agric 45: 39-45.

11. Nadeem MA, Ali A, Tahir M, Naeem M, Chadhar AR, \& Ahmad S (2010). Effect of nitrogen levels and plant spacing on growth and yield of cotton. Pak J Life Soc Sci 8: 121-124.

12. O'Berry NB, Faircloth JC, Edmisten KL, Collins GD, Stewart AM, Abaye AO, Herbert DA, \& Haygood JRA (2008). Plant population and planting date effects on cotton (Gossypium hirsutum L.) growth and yield. J Cotton Sci 12: 178187.

13. Iqbal M, \& Khan MA (2010). Management of cotton leaf curl virus by planting time and plant spacing. $A d v$ Agric Bot2: 25-33.

14. Ehsanullah, Shahzad MA, Anjum SA, Zohaib A, Ishfaq $M$, \& Warraich EA (2017). Effect of different sowing methods and planting densities on growth, yield, fiber quality and economic efficacy of cotton. Pak J Agric Res 30: 212-219.

15. Ali M, Ali L, Sattar M, \& Ali MA (2010). Responses of seed cotton yield to various plant populations and planting methods. $J$ Agric Res 48: 163-169.

16. Gursoy S, Sessiz A, Karademir E, Karademir C, Kolay B, Urgun M, \& Malhi SS (2011). Effects of ridge and conventional tillage systems on soil properties and cotton growth. Inter $J$ Plant Prod 5 (3): 227-236.

17. Butter GS, Aggarwal N, \& Singh S (2004). Productivity of American cotton as influenced by sowing date. Haryana $J$ Agron 20: 101-102.

18. Patel JG, Upadhyay PN, \& Kumar V (2009). Effect of depth of tillage and land configuration on yield and quality of cotton (Gossypium hirsutum L.) under south Gujarat condition. J Cotton Res Develop 23 (1): 64-67

19. Khan K, Mahmood Z, Soomoro AR, \& Elahi N (2005). Seed cotton yield as influence by different plant spacing under D. I. Khan. Environ Indus cotton 2: 147150.

20. Aslam M, Ahmed T, Sanghi AH, \& Khalid L (2018). Demonstration and evaluation of the effect of the yield response of seed cotton yield to various planting methods in ecological zone of Rahim Yar Khan. Inter J Adv Res Biol Sci 5: 95-99.

21. Nadeem MA, Idrees $M$, Ayub $M$, Tanveer A, \& Mubeen K (2013). Effect of different weed control practices and sowing methods on weeds and yield of cotton. Pak J Bot 45 (4): 1321-1328.

22. Maqbool MM, Tanveer A, Ali A, \& Ahmad R (2001). Effect of sowing methods and herbicides on weeds and yield of cotton. Pak J Bot 33: 383-387.

23. Gill MI (1999). Bed and furrow planting method ensures profitable seed cotton yield. Pak Cotton Grower 3: 10-11.

24. Ahmad A, Ali R, Zamir S, \& Mahmood $\mathrm{N}$ (2009). Growth, yield and quality performance of cotton cultivar BH-160 (Gossypium hirsutum L.) As influenced by different plant spacing. J Anim Plant Sci 19: 189-192.

25. Dong H, Li W, Tang W, \& Zhang D (2008). Furrow seeding with plastic mulching increases stand establishment and lint yield of cotton in saline field. $J$ Agron 100: 1640-1646.

26. Anwar MM, Gill ML, \& Zaki MS (2003). Effect of bed-furrow planting on cotton crop. Pak Cottons 47: 41-46.

27. Boquet DJ (2005). Cotton in ultra-narrow row spacing: plant density and nitrogen fertilizer rates. J Agron 97: 279-287.

28. Chauhan SK (2007). Seeding technique under saline water irrigation for cottonwheat rotation. Bhartiya Krishi Anusandhan Patrika 22: 430-437.

29. Iftikhar T, Babar LK, Zahoor S, \& Khan NG (2010). Impact of land pattern and hydrological properties of soil on cotton yield. Pak J Bot 42: 3023-3028. 
30. Makhdum MI (2004). Response of some cultivars to sulphate of potash and murate of potash. Ph.D. dissertation, Bahauddin Zakariya University, Multan.

31. Ali L, \& Ehsanullah (2007). Seed cotton yield and water use efficiency of cotton (Gossypium hirsutum L.) sown in different planting methods. Pak J Agric Sci 44: 571-574.

32. Quanqi L, Yuhai C, Mengyu L, Xunb Z, Baodi D, \& Songlie Y (2008). Water potential characteristics and yield of summer maize in different planting patterns. J Plant Soil Environ 1: 14-19.

33. Akbar HM, Akram M, Hassan MW, Hussain A, Rafay M, \& Ahmad I (2015). Growth, yield and water use efficiency of cotton (Gossypium hirsutum L.) sown under different planting techniques. Cust e Agronegócio on Line 11: 142-160.

34. Ali A, Tahir M, Ayub M, Ali I, Wasaya A, \& Khalid F (2009). Studies on the effect of plant spacing on the yield of recently approved varieties of cotton. Pak J Life Soc Sci 7: 25-30.

35. Halemani HL \& Hallikeri SS (2002). Response of compact and early maturing cotton genotypes to plant population levels under rain fed conditions. J Cotton Res Develop 16: 143-146

36. Siebert JD, Stewart AM, \& Leonard BR (2006). Comparative growth and yield of cotton planted at various densities and configurations. J Agron 98 (3): 562-568.

37. Jones MA, \& Wells R (1998). Fiber yield and quality of cotton grown at two divergent population densities. Crop Sci 38: 1190-1195.

38. Bednarz CW, Bridges DC, \& Brown SM (2000). Analysis of cotton yield stability across population densities. J Agron 92: 128-135.

39. Nicholas SP, Snipes CE, \& Jones MA (2004). Cotton growth, lint yield and fiber quality as affected by row spacing and cultivar. J Cotton Sci 8: 1-12.

40. Kalaichelvi K (2008). Effect of planting geometry and fertilizer levels on weed density and biomass in $\mathrm{Bt}$ cotton. Ind $J$ Weed Sci 40: 66-68.

41. Madavi B, Rani PL, Sreenivas G, \& Surekha K (2017). Effect of High Density
Planting and Weed Management Practices on Weed Dry matter, Weed Indices and Yield of Bt Cotton. Int J Pure Appl Biol Sci 5: 1945-1950.

42. Iqbal $M$, Ahmad S, Nazeer W, Muhammad T, Khan MB, Hussain M, Mehmood A, Tauseef M, Hameed A, \& Karim A (2012). High plant density by narrow plant spacing ensures cotton productivity in elite cotton (Gossypium hirsutum L.) genotypes under severe cotton leaf curl virus (CLCV) infestation. Afr J Biotechnol 11(12): 2869-2878.

43. Zhi XY, Han YC, Li YB, Wang GP, Du WL, Li XX, Mao SC, \& Lu FENG (2016). Effects of plant density on cotton yield components and quality. $J$ Integ Agric 15(7): 1469-1479.

44. Iqbal $\mathrm{M}$, Islam NU, Hayat $\mathrm{K}$, \& Muhammad T (2007). Management of cotton crop under high leaf curl virus attack. Asian J Plant Sci 6(7): 1125-1130.

45. Soomro AR, Soomro AW, Memon AM, Arain MH, \& Memon AA (2000). Yield response of four cotton cultivars under varying plant spacing at CCRI, Sakrand Sindh. Pak J Biol Sci 3(11): 1807-1808.

46. FAO (2014). World Reference Base for Soil Resources 2014. International Soil Classification System for Naming Soils and Creating Legends for Soil Maps. Available:

http://www.fao.org/publications/card/en/ c/942e424c-85a9-411d-a739$22 \mathrm{~d} 5 \mathrm{f} 8 \mathrm{~b} 6 \mathrm{cc} 41 /$

47. Meier U (2001). Growth Stages of Monoand Dicotyledonous Plants. Federal Biological Research Centre for Agriculture and Forestry, Berlin.

48. Singh MK, Singh RP, \& Singh RK (2003). Effect of crop geometry, cultivars and weed management on weed growth and yield of chickpea. Ind $J$ Weed $S c i$ 35(1 and 2): 45-48.

49. Moore JF (1996). Cotton Classification and Quality. P. 51-57. In: Glade J.R., L.A Meyer \& Stuits H. (ed.). The cotton industry in the united Status. USDA-ERS Agric. Econ. Rep. 739. U.S. Gov. Print. Office, Washington, DC.

50. Steel RGD, Torrie JH, \& Deekey DA (1997). Principles and Procedures of 
Statistics. A Biometrical Approach. $3^{\text {rd }}$ ED. McGraw Hill Book. Int. Co. New York. 5, 400-428.

51. Bukun B (2004). Critical periods for weed control in cotton in Turkey. Weed Research 44: 404-412.

52. Wang C, Isoda A, \& Wang P (2004). Growth and yield performance of some cotton cultivars in Xinjiang, China, an arid area with short growing period. $J$ Agron Crop Sci 190: 177-183.

53. Cheema MS, Nasrullah M, Akhtar M, \& Ali L (2008). Comparative efficacy of different planting methods and weed management practices on seed cotton yield. Pak J Weed Sci Res 14: 153-159.

54. Ortega AL, Mir EV, \& Rangel EE (2008). Nitrogen management and wheat genotype performance in a planting system on narrow raised beds. Cereal Res Commun 36: 343-352.

55. Prasad M, \& Prasad R (1993). Productivity of upland cotton (Gossypium hirsutum) genotypes under different levels of nitrogen and spacing. Ind J Agron 38: 606-608.

56. Ali M, Ali L, Waqar MQ, \& Ali MA (2012). Bed planting: A new crop establishment method for wheat (Triticum aestivum L.) in cotton-wheat cropping system of Southern Punjab. Int J Agric Appl Sci 4: 8-14.

57. Krause U, Koch HJ, \& Maerlaender B (2009). Soil properties effecting yield formation in sugar beet under ridge and flat cultivation. Eur J Agron 31: 20-28.

58. Graig WC, David B, \& Steve MB (2000). Analysis of cotton yield stability across population densities. J Agron 92: 128135.

59. Maqsood M, Hussain T, Tayyab M, \& Ibrahim M (2006). Effect of different irrigation levels on the yield and radiation use efficiency of cotton (Gossypium hirsutum) under two sowing methods. Pak J Agric Sci 43: 21-24.

60. McAlavy TW (2004). Researchers investigate cotton irrigation strategies.
Agricultural Communications, Taxas, A and M University System, College Station, TX, USA.

61. Khan SU, \& Ullah K (1991). Effect of various planting methods on seed cotton yield. Pak Cotton 35: 43-47.

62. Nehra PL, \& Kumawat PD (2003). Response of Hirsutum cotton varieties to spacing and nitrogen levels. J Cotton Res Develop 17(1): 41-42.

63. Gwathmey CO, \& Craig CC (2003). Managing earliness in cotton with mepiquat-type growth regulators. Crop Manag 8: 12-15.

64. Siddiqui MH, Oad FC, \& Buriro UA (2007). Plant spacing effects on growth, yield and lint of cotton. Asian J Plant Sci 6: 415-8.

65. Delaney DP, Monks CD, Revess DW, Bannon JS, \& Durbin RM (1999). Planting dates and populations for UNR cotton in central Alabama Proceedings Beltwide Cotton Conference. pp.12781279.

66. Brodrick R, Bange MP, Millroy SP, \& Hammer GL (2013). Physiological determinants of high yielding ultranarrow row cotton: Canopy development and radiation use efficiency. Field Crops Res 148: 86-94.

67. Yang CQ, Li XH, \& Yang DY (2014). Effects of nitrogen fertilizer on the $\mathrm{Bt}$ protein content in transgenic cotton and the mechanism of nitrogen metabolism. Cotton Sci 17: 227-231.

68. Kerby T, Cassman K, \& Keeley M (1990). Genotypes and plant densities for narrow-row cotton systems. I Height, nodes, earliness, and location of yield. Crop Sci 30: 644-649.

69. Heitholt JJ, Pettigrew WT, \& Meredith WR (1992). Light interception and lint yield of narrow row cotton. Crop Sci 32: 728-733.

70. Hussain S, \& Qasim M (2003). Effect of plant population on some physiological parameters of cotton. J Agron 7: 229232. 